KENOSIS : JURNAL KAJIAN TEOLOGI

ISSN 2460-6901(Print), 2656-4483 (Online)

https://e-journal.iaknambon.ac.id/index.php/KNS

DOI: $10.37196 /$ kenosis.v7i2.391

\title{
Perubahan Agama Minahasa Dan Kekristenan Dalam Konstruksi Perjumpaan Simbol Sakral Pada Ritual Di Watu Pinawetengan
}

\section{Hun Johanis A. Pinatik, Izak Y. M. Lattu, Rama Tulus Pilakoannu}

\author{
Magister Sosiologi Agama \\ Fakultas Teologi \\ Universitas Kristen Satya Wacana \\ Jalan Diponegoro 52 - 60 Salatiga 50711 \\ lattu@staff.uksw.edu
}

\begin{abstract}
This article aims to explore the conversion of Minahasa and Christianity religion through mutually constructed efforts carried out by the community of ritual practitioners in Watu Pinawetengan. This research focuses on the mutual change between Minahasa religion and Christianity in rituals through the construction of a symbolic encounter by the ritual-playing community at Watu Pinawetengan. For ritual practitioners, Watu Pinawetengan is a sacred place Tou Minahasa (Minahasa man) that is located in North Sulawesi Province, Minahasa Regency. Individuals in a community construct the meaning of each symbol, thus creating a paradigm of religion. Sacred symbols refer to the essence of a belief in religion, so it is crucial in describing the existence of a religion. The data is taken through the use of qualitative methods by conducting observations, interviews, library studies, and documentary studies. The findings of this study show that changes in sacred symbols in rituals have been constructed in Minahasa and Christian discourses, resulting in a mutual change in both religions. Change occurs dialectically and is strengthened by the legitimacy of the ancestral spirit.
\end{abstract}

Keywords: Religious shange, Sacred symbols, Rituals, Minahasa, Christianity, and Social Construction

\begin{abstract}
Abstrak
Artikel ini bertujuan untuk menggali perubahan agama Minahasa dan Kristen melalui upaya saling mengonstruksi yang dilakukan oleh komunitas pelaku ritual di Watu Pinawetengan. Fokus penelitian pada perubahan bersama, antara agama Minahasa dan Kristen dalam ritual melalui konstruksi perjumpaan simbol oleh komunitas pelaku ritual di Watu Pinawetengan. Bagi
\end{abstract}


pelaku ritual, Watu Pinawetengan merupakan tempat sakral Tou Minahasa (manusia Minahasa) yang berada di Provinsi Sulawesi Utara, Kabupaten Minahasa. Individu-individu dalam komunitas mengonstruksi makna dari setiap simbol sehingga menciptakan paradigma fundamen tentang agama. Simbol sakral merujuk pada esensi dari suatu kepercayaan dalam agama, sehingga bersifat krusial dalam menggambarkan eksistensi suatu agama. Data diambil melalui penggunaan metode kualitatif dengan melakukan observasi, wawancara, studi pustaka, dan studi dokumenter. Temuan dari studi ini memperlihatkan perubahan simbol sakral dalam ritual telah dikonstruksi dalam diskursus agama Minahasa dan Kristen, sehingga mengakibatkan perubahan bersama pada kedua agama tersebut. Perubahan terjadi secara dialektis dan diperkuat dengan legitimasi roh leluhur.

Kata kunci: Perubahan agama, Simbol sakral, Ritual, Minahasa, Kristen, Konstruksi sosial

\section{PENDAHULUAN}

Artikel ini bertujuan untuk menggali proses perubahan agama Minahasa dan Kristen melalui upaya saling mengonstruksi simbol sakral yang dilakukan oleh komunitas pelaku ritual di Watu Pinawetengan. ${ }^{1}$ Dalam ritual yang dilakukan terdapat berbagai simbol sakral yang memiliki makna dan memori penting. Bagi mereka ritual merupakan ruang pertemuan antara Tou Minahasa dengan roh leluhur. Karena itu, ritual mengandung aspek simbolis yang menjadi identitas suatu agama. Namun di masa kini, ritual keagamaan Minahasa atau agama Minahasa itu sendiri telah mengalami perubahan. Hal yang sama juga terjadi pada agama Kristen, ketika terjadi konstruksi antara agama Minahasa dan Kristen oleh para pelaku ritual. Perubahan pada Minahasa dan Kristen tidak terlepas dari sejarah perjumpaan Minahasa dan Kristen.

Minahasa memiliki sejarah panjang dalam perjumpaan dengan bangsa Barat, khususnya agama Kristen. Perjumpaan terjadi sejak zaman leluhur Minahasa bertemu dengan pihak Kolonial. Relasi antara Minahasa dan pihak kolonial adalah relasi antara penjajah dengan yang terjajah. Namun, pihak Kolonial tidak hanya datang sebagai penjajah yang mempekerjakan orang Minahasa. Pihak Kolonial datang bersama para zending (penginjil) yang membawa ideologi semangat pietis (penekanan pada kesalehan). ${ }^{2}$ Ideologi yang datang dari negeri barat ini memicu 
adanya superioritas, ${ }^{3}$ sehingga menegasikan agama Minahasa. Dalam perjalanan waktu, maka orang-orang Minahasa sebagian besar beragama Kristen. Mengakibatkan para pelaku ritual yang masih mempertahankan kepercayaan dari para leluhur melakukan kolaborasi dengan simbol-simbol dalam agama Kristen. Akhirnya, ritual di Watu Pinawetengan identik dengan konstruksi simbol Kristen. Walaupun demikian, kolaborasi antara Minahasa dan Kristen memicu kontestasi bahkan ambiguitas antara kedua agama tersebut. Hal ini karena perubahan yang terjadi pada kedua agama tersebut, yakni perubahan memori, sakralitas, identitas, ritual dan khususnya pemaknaan simbol.

Relasi Kekristenan dan Budaya Minahasa adalah hal menarik yang telah dijelaskan dalam beberapa penelitian sebelumnya. ${ }^{4}$ Penelitian-penelitian ini mengkaji persoalan multi-identitas para pelaku ritual, aspek sejarah dalam perjumpaan gereja adat, kolektivitas Minahasa, keunggulan Manusia Minahasa dan dinamika budaya, pengaruh politik dalam transformasi budaya dan agama di Minahasa, dan dampak kolonisasi terhadap perubahan agama di Minahasa.

Berbeda dengan penelitian-penelitian sebelumnya, artikel ini melihat bagaimana simbol sakral digunakan dalam konteks hibrid. Bagaimana masyarakat Minahasa mengonstruksi makna baru dari simbol-simbol agama yang digunakan dalam ritual. Bagaimana masyarakat Minahasa yang memiliki keragaman identitas memahami multiplisitas dalam ruang ritual melalui simbol sakral. Karena itu, penelitian ini akan menggali secara mendalam mengenai perubahan agama Minahasa dan Kristen secara bersama dalam ritual yang terkait dengan konstruksi simbol sakral oleh komunitas pelaku ritual di Watu Pinawetengan. Argumentasi utama dalam artikel ini: perubahan agama Minahasa dan Kristen terjadi karena pemaknaan baru terhadap simbol sakral melalui proses konstruksi oleh komunitas pelaku ritual. Bahkan pemaknaan tersebut dilegitimasikan berdasarkan wahyu yang diberikan oleh roh leluhur Minahasa. Perjumpaan simbol sakral (simbol Minahasa dan Kristen) pada ritual di Watu Pinawetengan mengubah identitas kultural-religius dari Tou Minahasa. Komunitas pelaku ritual bersikap defensif terhadap identitas kulturalnya sebagai Tou Minahasa (manusia Minahasa), namun berada dalam diskursus Kekristenan.

Penelitian ini menggunakan pendekatan Religious Change dari Jack D. Eller yang menjelaskan bahwa agama tidak bersifat konservatif, tetapi lebih bersifat 
dinamis. Agama yang tradisional sekalipun akan tetap memperoleh ide baru untuk mengalami perubahan. Bahkan beberapa agama dikembangkan melalui faktor nonreligius seperti politik, budaya popular, teknologi, dan lainnya. Karena itu, ide tentang agama bisa ditemukan dalam perjumpaannya dengan yang lain. ${ }^{5}$ Selain Eller, Peter L. Berger dalam konsepnya tentang konstruksi sosial, mengatakan bahwa setiap manusia atau masyarakat merupakan usaha untuk mengonstruksi dunia. Makna mengonstruksi di sini berarti membangun kenyataan melalui aktivitas manusia itu sendiri. ${ }^{6}$

\section{METODE PENELITIAN}

Tulisan ini menggunakan metode penelitian kualitatif. Dengan jenis penelitian deskriptif-analitis. Penelitian kualitatif menekankan sifat realitas yang dikonstruksi secara sosial, hubungan intim antara peneliti dan subyek penelitian, serta kendalakendala situasional yang membentuk inkuiri. ${ }^{7}$ Teknik pengumpulan data yang digunakan, pertama melalui observasi pada ritual di Watu Pinawetengan untuk bisa mengetahui secara langsung obyek formal yang diteliti. Kedua, melalui wawancara kepada aktor sosial (pemimpin ritual), anggota komunitas penghayat kepercayaan lokal Minahasa, dan budayawan Minahasa tentang makna dibalik penggunaan simbol sakral pada ritual. Wawancara yang dilakukan secara langsung, tetapi juga via telepon. Ketiga, melalui studi dokumenter dan pustaka. Studi dokumenter digunakan untuk mencari data terkait ritual di Watu Pinawetengan melalui foto atau video dari media online/ internet. Studi pustaka yaitu mencari teori dan data yang berkaitan dengan penelitian ritual di Watu Pinawetengan Minahasa. Setelah pengumpulan data, maka peneliti akan melakukan reduksi data. Kemudian display data, lalu verifikasi dan kesimpulan penelitian.

\section{HASIL DAN PEMBAHASAN}

\section{Perubahan Agama dan Konstruksi Sosial}

Agama sering dipahami oleh masyarakat umum sebagai bentuk relasi dengan

Tuhan yang konservatif. Aspek dinamis dalam agama dianggap tidak ada, sehingga agama cenderung dipahami bersifat statis. Pembaharuan yang transformatif untuk mengubah tradisi dalam konten agama menjadi hal yang tidak terhindarkan. ${ }^{8}$ Sebuah 
pepatah kuno mengatakan tempus muntantur, et nos mutamur in illid, bahwa waktu berubah dan kita juga turut berubah bersamanya. ${ }^{9}$ Beragam hal dalam dunia akan mengalami perubahan dengan berjalannya waktu, begitu pun dengan agama. Bagi Eller, agama bisa mengalami perubahan melalui perjumpaan dengan berbagai entitas dalam realitas manusia. Perjumpaan dengan agama lain atau dinamika ideologi politik, budaya, dan teknologi memungkinkan terjadinya perubahan pada agama yang lama. $^{10}$

Agama akan terus mengalami perkembangan sebagaimana manusia juga berkembang. ${ }^{11}$ Sejalan dengan itu, Bagi Taylor agama merupakan representasi dari evolusi pemikiran manusia. ${ }^{12}$ Menurut Eller perubahan dari suatu agama adalah realitas yang tidak terhindarkan dengan berbagai proses di dalamnya, sehingga perspektif sempit tentang agama yang statis perlu untuk dipikirkan kembali. Perubahan agama bagi Eller bisa terjadi akibat perubahan pada konstelasi sosial dan lingkungan. Modernisasi adalah salah satu faktor dari perubahan agama. Sebab modernisasi menyediakan preferensi untuk mengonversi sebuah ideologi, entah dari agama ataupun budaya. Agama tradisional sering diasumsikan bersifat konservatif, dengan tendensi tidak mau membangun relasi bersama pihak di luar dirinya. Namun, Eller mengungkapkan bahwa agama tradisional memiliki sifat yang dinamis atau bisa mengalami transisi. Kontak dengan yang berbeda atau perjumpaan adalah suatu metode untuk mengalami perubahan. ${ }^{13}$

Terjadinya perubahan membutuhkan peran dari manusia. Teori kritis mengajukan tesis bahwa perubahan bisa terjadi melalui peran aktif dari kesadaran manusia untuk berkomunikasi dan berdialog dengan yang lain. Proses dialog dan komunikasi mewajibkan adanya keterbukaan antara kedua pihak. ${ }^{14}$ Karena itu, peran dari manusia untuk terbuka dengan beragam ide di luar agama yang dianutnya menjadi kunci dasar dari perubahan tersebut. Perjumpaan dengan ide berbeda bisa menciptakan percampuran paradigma. Oleh Eller disebut sebagai sinkretisme. Paham sinkretis dalam sudut pandang Eller berada pada tataran positif. Dia mereduksi pola mendiskreditkan agama yang sinkretik oleh pandangan umum. Risiko paling ekstrem dari sinkretisme adalah punahnya agama yang lama akibat muncul ide baru dalam perubahan. ${ }^{15}$ Bisa juga dengan mencari sistem-sistem budaya atau agama yang memiliki kesamaan. ${ }^{16}$ Tujuannya supaya membuat penyesuaian berdasarkan 
persamaan tersebut. Walau demikian, ide tentang peran manusia dalam perkembangan agama juga tidak sejalan dengan pemikiran Feuerbach. Bagi Feuerbach, agama sebagai bentuk proyeksi manusia. ${ }^{17}$ Ide ini akan membahayakan pemahaman agama tentang sakralitas.

Percampuran antara agama bisa membuka ruang inklusif untuk berinteraksi dengan yang berbeda, akibat dasar pengalaman. Di sisi lain percampuran bisa menjadi ancaman untuk menutup diri dengan yang berbeda, jika percampuran mengambil ideologi fundamental dari agama-agama lama. Tidak hanya mengenai percampuran yang bersifat sinkretis, tetapi Eller menjelaskan tentang adanya revitalisasi. Sinkretisme dan revitalisasi adalah bagian dari New Religious Movement dari Religious Change yang diformulasikan pada teorinya Eller. Melalui revitalisasi, maka disrupsi budaya dan agama lama bisa dihidupkan kembali. Masalah dalam masyarakat adalah faktor terjadinya revitalisasi pada agama atau budaya. Realitas absurd sebagai problematik masyarakat menciptakan ruang dilematis yang memungkinkan terjadi revitalisasi. Masalah sosial merupakan realitas yang absurd, sebagai antinomi tentang kegelisahan masyarakat, yang bisa dipahami sebagai faktorfaktor pendukung proses revitalisasi. ${ }^{18}$

Selain Eller, Berger dalam bukunya The Sacred Canopy menjelaskan tentang konstruksi realitas. Manusia dalam pandangan Berger bukan hanya sekedar Homo Sapiens, tetapi juga merupakan Homo Socius. ${ }^{19}$ Sebagai Homo Socius, maka manusia hidup dalam relasi antara satu dengan yang lain. Manusia berarti tidak bisa hidup sendiri, sehingga akan selalu berjumpa dengan lain. Akibatnya maka manusia akan bertemu dengan liyan atau manusia dengan kebudayaan berbeda. Melalui pertemuan ini akan ada perluasan diri. ${ }^{20}$ Interaksi antar manusia dapat terjadi melalui realitas hidup sehari-hari. ${ }^{21}$ Kemudian dalam proses interaksi ini, maka manusia akan mengeluarkan produk-produk eksternalnya, di sini mulai terjadi proses transformasi dari dalam subyektifitas menuju ke dalam dunia. Dengan kata lain, manusia akan menghadapi sebuah faktisitas dari produk yang telah dia buat. ${ }^{22}$ Dalam konteks ritual di Watu Pinawetengan, produk manusia berupa simbol-simbol sakral dalam ritual. Simbol yang dieksternalisasi ini, berada dalam dunia obyektif yang bersifat dialektis karena interaksi antar manusia. 
Konstrusi sosial dalam pandangan Berger, mengharuskan terjadinya proses dialektis. Proses tersebut adalah Eksternalisasi, obyektivasi, dan internalisasi. Eksternalisasi adalah pengeluaran subyektivitas manusia ke dalam realitas atau dunia. Obyektivasi adalah berhadapannya suatu realitas yang telah terbentuk dari subyektivitas manusia kepada dirinya sendiri atau pun yang lain, sehingga membentuk faktisitas. Kemudian internalisasi adalah peresapan kembali realitas yang telah terbentuk oleh manusia. ${ }^{23}$ Bagi Berger, agama merupakan sebuah usaha aktivitas manusia untuk membentuk kosmos sakral atau kosmisasi yang sakral. Konsep sakral yang diuraikan Berger berada dalam konteks beragam. Sehingga keseragaman ini akan ditafsirkan sebagai akibat dari penyebaran budaya. ${ }^{24}$ Dunia atau kenyataan yang dipahami oleh Berger sebagian besar dipenuhi oleh sakralitas. Intinya, Berger menjelaskan bahwa manusia memiliki eksistensi untuk secara terus menerus melakukan aktivitas eksternalisasi membentuk kenyataan. ${ }^{25}$ Dengan kata lain, bahwa dunia yang dimiliki oleh manusia diinterpretasikan dalam konteks sakralitas agama atau kepercayaan.

\section{Dari Agama Tua Minahasa Ke Ritual Bersimbol Kristen di Watu Pinawetengan}

Minahasa pada awalnya menggunakan kata Malesung, bertujuan menjelaskan keturunan atau taranak. Secara topografi, Malesung berhubungan dengan tanah Minahasa yang berbentuk lesung atau tempat menumbuk padi, karena terdiri dari pegunungan dan lembah. Namun kemudian menjadi Minahasa karena kepentingan politis Belanda untuk menyatukan seluruh keturunan Malesung. ${ }^{26}$ Sedangkan Watu Pinawetengan merupakan tempat berkumpulnya para keturunan Toar-Lumimu'ut ${ }^{27}$ sebagai orang Minahasa. Tujuan mereka berkumpul untuk bermusyawarah menentukan batas wilayah dan bahasa. Pada masa kini, Watu Pinawetengan merupakan sebuah batu yang ramai didatangi oleh pelaku ritual. Mereka datang untuk melakukan ritual dengan tujuan bertemu dengan roh leluhur. Tuhan merupakan leluhur pertama dalam pandangan orang Minahasa. ${ }^{28}$

Sebelum Kekristenan masuk di Minahasa, penduduk lokal sudah memiliki kepercayaan. Mereka memiliki mitos, kultus, dan ritus. Mitos yang umum adalah cerita tentang Toar-Lumimu'ut dan Karema sebagai latar genealogi orang Minahasa. ${ }^{29}$ Dalam kultus orang Minahasa, roh leluhur memiliki posisi yang sangat 
penting. Roh leluhur sering disebut sebagai opo/apo yaitu representasi Ilahi. Nama leluhur yang paling sering disebut adalah Opo Empung dan Apo Kasuruan. ${ }^{30}$ ToarLumimu'ut dan keturunannya pun dipercaya sebagai leluhur Minahasa. Sedangkan ritus dalam agama tua Minahasa berupa ritual. Pelaksanaan ritual dipimpin oleh orang dengan jabatan agama atau religi Minahasa. Terdapat beberapa jenis ritual dalam kepercayaan atau agama tua Minahasa, yaitu poso keluarga dan poso negeri. ${ }^{31}$ Namun sejak kedatangan agama Kristen di Minahasa, maka mulai terjadi kristenisasi, oleh misionaris Katolik dan Protestan bersamaan dengan kepentingan dagang dan perluasan kekuasaan dari Portugis dan Belanda. ${ }^{32}$

Penganut agama Minahasa mengalami tantangan untuk bertahan dari pengaruh para zending yang berusaha menegasikan ritual Minahasa. Tindakan menegasikan ritual sama saja dengan mereduksi esensi dari agama Minahasa. Karena itu, terjadi penolakan dari pihak Minahasa terhadap penetrasi agama Kristen. Hal ini dikarenakan pemeluk agama Minahasa dianggap sebagai alifuru (kafir) oleh pihak Barat. ${ }^{33}$ Alifuru memiliki konotasi yang buruk, sebab menghilangkan nilai-nilai kesakralan kepercayaan agama Minahasa. Selain itu, orang Minahasa juga menjadi objek dari pihak kolonial Barat, yaitu Portugis, Spanyol, dan terutama Belanda dalam membentuk pola tradisi. Dengan demikian, orang Minahasa telah mengalami penetrasi Barat secara intens. ${ }^{34}$

Melalui episode sejarah kedatangan bangsa Barat beserta agama Kristen di dalamnya tentu menunjukkan keberhasilan dalam proses Kristenisasi di Minahasa. Hetty Palm dalam tulisannya The Ancient Art of Minahasa, menjelaskan bahwa Minahasa hampir mengalami kepunahan soal kebudayaannya pada abad ke-19. Bagi Kaunang, tesis hampir punahnya kebudayaan Minahasa tidak terlepas dari intervensi asing yang kuat. ${ }^{35}$ Membuat orang Minahasa tidak terlepas lagi dari identitas agama Kristen di masa kini. Karena itu, melihat orang Minahasa yang telah beragama Kristen merupakan hal lumrah. Akhirnya agama Kristen menjadi dominan di Minahasa.

Minahasa dan Kristen adalah dua entitas yang berbeda, karena memiliki asalusul yang tidak sama. Minahasa memiliki kepercayaan terhadap leluhur, ${ }^{36}$ sedangkan agama Kristen menentang kepercayaan tersebut. Hal ini karena Kekristenan yang datang di Minahasa dari latar pietis. Pietisme sendiri merupakan paham yang identik 
dengan Nederlandsch Zendeling Genootschaap (NZG), sebagai lembaga penginjilan di Minahasa. ${ }^{37}$ Graafland menjelaskan bahwa agama Minahasa telah mengalami pengaruh dari agama Kristen, sehingga narasi legenda mereka mengalami perubahan. ${ }^{38}$

Akibat dari dominasi agama Kristen, maka terjadi perubahan dalam kepercayaan dan ritual orang Minahasa. Para pelaku ritual dianggap sesat dan menyembah batu atau roh orang mati oleh pihak dominan, yaitu agama Kristen. Ritual dan simbol sakral ditinggalkan oleh sebagian besar orang Minahasa yang beragama Kristen. Akhirnya, Minahasa saat ini cenderung beragama Kristen dan tidak lagi melaksanakan ritual. Walaupun demikian, terdapat beberapa komunitas yang masih mempertahankan ritual dan simbol agama Minahasa. Mereka tetap berpegang pada ajaran leluhur Minahasa melalui praktik ritual di tempat dan waktu sakral yang dipercaya. Di mana agama Kristen berdampingan dengan agama Minahasa yang telah mengalami kebangkitan kembali. ${ }^{39}$

Para pelaku ritual yang beragama Kristen menggunakan simbol-simbol Kristen dalam praktik ritual di Watu Pinawetengan. Simbol-simbol tersebut berupa Alkitab, salib, nyanyian rohani, dan bahasa religius Kristen. Pada kenyataannya simbol-simbol ini bertentangan dengan kepercayaan Minahasa, jika melihat sejarah perjumpaan antara Kristen dengan Minahasa yang dibingkai dalam semangat pietis. Namun tidak bisa dipungkiri bahwa ritual di Watu Pinawetengan telah menggunakan perpaduan antar simbol Minahasa dengan Kristen. Padahal Watu Pinawetengan sebagai axis mundi orang Minahasa, jika meminjam istilah dari Eliade. ${ }^{40}$ Sebagai axis mundi, maka Watu Pinawetengan menjadi tempat sakral bagi orang Minahasa yang tidak boleh sembarang disentuh atau dielaborasi dengan hal-hal profan atau berbeda dari pengetahuan yang leluhur berikan.

\section{Perubahan Agama Minahasa dan Kristen: Bahaya dan Peluang}

Hadirnya simbol Kristen dalam ritual dan tempat sakral orang Minahasa menandai adanya konstruksi simbolik baru sebagai entitas perubahan agama. Namun, perubahan ini tidak bisa dipandang hanya terjadi pada agama Minahasa saja, tetapi juga terjadi terhadap agama Kristen. Pada kenyataannya, pelaku ritual memegang dua kepercayaan agama secara bersama, yaitu Kristen dan lokal Minahasa. Konsekuensi 
logis bahwa tindakan dari penggabungan antara agama Minahasa dengan Kristen turut mengubah kebiasaan penggunaan simbol, ritus, doktrin, narasi, dan makna. Akibatnya agama Minahasa dan Kristen yang umum dipandang harus bersifat murni, kini mengalami dinamika transformatif.

Minahasa dan Kristen menjadi dua hal yang tidak bisa terpisahkan dalam kehidupan komunitas pelaku ritual. Mereka mengonstruksi simbol Kristen dalam ritual Minahasa dan terus mengeksternalisasikan beragam interpretasi tentang maknamakna baru. Umumnya setiap Tona'as memiliki interpretasinya sendiri tentang ritual dan simbol yang dilangsungkan. Sehingga perubahan terus terjadi dalam dinamika agama Minahasa dan Kristen di Watu Pinawetengan.

Walaupun agama Kristen adalah yang dominan dalam kultur dan kepercayaan Minahasa, namun bukan berarti tidak ada tempat lagi bagi agama lain. Faktanya dalam ritual di Watu Pinawetengan terdapat penggunaan Kitab Suci dari agama Islam. Bukan hanya itu saja, pelaku ritual di batu ini ada juga yang beragama Buddha. Memang pelaku ritual yang non-Kristen sangat minim ditemukan, tetapi bukan berarti tidak ada. Batu ini merupakan tempat ibadah bagi semua agama dan bebas dimasuki oleh kebudayaan manapun. ${ }^{41}$ Sejalan dengan pandangan dari Eller bahwa agama tidak bersifat konservatif, namun terbuka dengan perubahan. ${ }^{42}$ Budaya dan agama Minahasa memang dimiliki oleh Tou Minahasa. Namun tetap membuka ruang perjumpaan dengan agama lain. Oleh Sugiharto disebut sebagai era post-tradisi, yaitu interaksi bebas dan tak bisa dibendung. ${ }^{43}$ Karena itu, Minahasa sebagai budaya dan agama adalah entitas yang inklusif bagi entitas-entitas lain di luar dirinya.

Minahasa yang terbuka terhadap perkembangan zaman, tentunya bisa berakibat fatal dan berbahaya bagi eksistensinya sendiri. Identitas Minahasa bisa mengalami kekaburan, bahkan lebih buruk lagi kehilangan identitasnya. Seorang Tona'as menjelaskan bahwa tradisi Minahasa telah dimusnahkan oleh pihak Kolonial, sehingga orang Minahasa telah tercabut dari akarnya. ${ }^{44}$ Pihak zending memang memiliki kesulitan untuk menyesuaikan diri dengan kepercayaan hidup masyarakat Minahasa, sebab orientasi misi mereka adalah sikap pietis (penekanan pada kesalehan) dan pertobatan terhadap orang lokal (Minahasa). ${ }^{45}$ Minahasa yang telah memiliki kepercayaan terhadap Opo Walian Wangko (Tuhan Minahasa), jika dilihat dalam persepsi Barat tentunya menghasilkan gagal persepsi terhadap esensi 
Minahasa. Memahami Minahasa yang dari luar dirinya akan terjebak pada orientalisme. ${ }^{46}$ Karena itu, perspektif perubahan agama oleh Eller tentu adalah sebuah tanda tanya besar terhadap eksistensi agama dan keberlanjutannya. Apalagi pengaruh Kekristenan terhadap Minahasa berabad lamanya.

Namun, perkembangan zaman tidak hanya mendestruksi Minahasa, tetapi memberi akses terhadap pengenalan akan budaya lama yang telah dilupakan. Kebudayaan Minahasa yang mengalami reduksi dan hampir punah, dikonstruksi kembali lewat berbagai proses. Salah satunya melalui hasil penelitian dari anak zending Riedel, yang menemukan sebuah batu bernama "Watu Pinawetengan" melalui proses eskavasi. Watu Pinawetengan bukan sekedar batu biasa, namun menjadi simbol kebijaksanaan dan simbol konsensus dari para pemimpin Minahasa zaman dahulu. ${ }^{47}$ Seorang Tona'as menjelaskan bahwa Watu Pinawetengan adalah tempat mengingat terhadap para leluhur. ${ }^{48}$ Memang awal kedatangan Kolonial yang erat dengan zending mengisahkan episode sejarah penghancuran terhadap tradisi Minahasa. Sebaliknya, tidak bisa dipungkiri bahwa terdapat sumbangsih positif dari pihak zending yang menuliskan cerita-cerita tentang budaya Minahasa untuk membangkitkan kembali semangat "keminahasaan."49

Minahasa masa kini sebagai hasil dari penginjilan oleh zending terpecah dalam berbagai persepsi tentang agama (kepercayaan). Ada yang tetap bertahan sebagai Tou Minahasa yang tidak berhubungan dengan simbol Kristen pada ritual. Bertahan sebagai orang berkebudayaan Minahasa yang beragama Kristen dan tidak suka dengan ritual, sebab ritual di batu dianggap kafir (sesat). Bertahan sebagai orang yang berkebudayaan Minahasa dengan menjalankan ritual dan menggunakan simbolsimbol Kristen serta tanpa meninggalkan Kekristenan sebagai identitasnya. Bahkan beberapa yang konservatif secara paradigmatis, sampai mengeluarkan narasi kontestasi di ruang publik. Guna membela dan menyatakan bahwa agama mereka yang terbenar. Dalam konteks ini, maka perubahan agama juga menjadi pertanyaan terhadap harmonisasi beragama. Sekaligus proses penafsiran dunia sebagai bentuk eksternalisasi antar manusia dengan kepercayaan berbeda menjadi tantangan, sekaligus bahaya.

Kontestasi ruang publik masyarakat Minahasa diakibatkan karena preferensi kepercayaan berbeda, yang mewujud dalam aktualisasi simbol sakral pada setiap 
kepercayaan. Setiap simbol bersifat sui generis dalam tataran obyektivasi. ${ }^{50}$ Maksudnya bahwa setiap simbol adalah kenyataan dari masing-masing orang atau komunitas dengan kepercayaan yang dianutnya. Masyarakat Minahasa yang masih melakukan ritual di batu memiliki sumber ajaran berupa narasi dari leluhur (melalui orang yang sedang trans). Sebab narasi adalah cara untuk mentransfer pengetahuan kepada seluruh anggota komunitas. Lattu menjelaskan bahwa oralitas sebagai bagian krusial dalam ingatan bersama pada masyarakat dengan budaya lisan. ${ }^{51}$ Berbeda dengan Kristen memiliki ajaran yang berdasar pada Alkitab sebagai bentuk tertulis. Pada pokok ini agama Kristen sebagai agama impor bersifat kontradiktif dengan agama lokal Minahasa.

Kontradiksi juga dipicu akibat pengrusakan nilai-nilai kepercayaan Minahasa terhadap roh leluhur. Pandangan kafir terhadap pelaku agama lokal yang melakukan ritual di batu, waruga (kubur leluhur Minahasa), dan di rumah-rumah ikut mendestruksi nilai kepercayaan lokal. Sopacoly menjelaskan bahwa terdapat asumsi negatif tentang pelaku ritual di waruga, dengan menganggap mentuhankan kubur batu oleh masyarakat beragama Kristen. ${ }^{52}$ Foucault menjelaskan bahwa fenomena tubuh sosial bukan karena konsensus, tetapi pengaruh kekuasaan yang beroperasi. ${ }^{53}$ Sikap politis terhadap realitas sosial masyarakat ditentukan oleh yang memiliki kuasa tentang yang benar dan salah. Secara faktual agama Kristen adalah dominan di Minahasa.

Akan menjadi pertanyaan penting, apakah perjumpaan antara Minahasa dengan Kekristenan dalam episode sejarah, sehingga terjadi perubahan merupakan kesalahan. Pertanyaan ini sukar dijawab, karena agama dan budaya bisa mengalami perubahan. Perubahan praktik agama bisa terjadi akibat perubahan keadaan sosial, teknis, atau lingkungan. ${ }^{54}$ Dengan kata lain tidak ada ide yang murni dalam suatu agama, tanpa campur tangan dengan pengetahuan lain. Minahasa telah mengalami perubahan identitas sosial melalui kontak ideologi berbeda dengan masyarakat Barat atau Kristen. Namun, bukan berarti perubahan yang terjadi pada masyarakat harus merusak kebudayaan atau memusnahkan nilai-nilai lokal yang dianut. Bagi Sen, setiap manusia memiliki banyak identitas dalam dirinya sesuai konteks tempat dia hidup. ${ }^{55}$ Abdul Halim Athiah menjelaskan bahwa reformasi dalam agama Islam merupakan inti gagasan yang penting supaya bisa mencapai perkembangan. ${ }^{56}$ 
Konversi kepercayaan dalam nilai agama dan budaya dari tou Minahasa diakibatkan oleh adanya pencarian wawasan, pengetahuan, dan makna baru. ${ }^{57}$ Perjumpaan antara Minahasa dan Kristen adalah sebuah perjalanan panjang dari evolusi suatu masyarakat yang beragama, dengan tetap waspada pada perubahan agar tidak menghilangkan esensi dari nilai-nilai lokal keminahasaan.

\section{Perubahan Ritual dan Konstruksi Perjumpaan Simbol Sakral}

Ritual adalah ruang pertemuan dengan Yang Sakral dan tempat mengkonstruksi relasi kolektif komunitas. Seorang Tona'as menjelaskan bahwa $b a$ ator (sebutan ritual orang Minahasa) adalah perayaan kehidupan dengan bersyukur kepada Sang Khalik. ${ }^{58}$ Ritual atau foso sudah terjadi sejak zaman Toar dan Lumimuut yang mempersembahkan foso ucapan syukur kepada Tuhan atas perkawinan mereka. ${ }^{59}$ Durkheim menjelaskan bahwa praktek ritual merepresentasikan kolektivitas komunitas sebagai dampak sosial dari keterlibatan anggota. ${ }^{60}$ Sedangkan bagi Eliade, ritual bukan hanya menjelaskan tentang realitas sosial, tetapi entitas Yang Sakral (bersifat supranatural). ${ }^{61}$ Ritual di Watu Pinawetengan adalah representasi dari rasa syukur komunitas terhadap Tuhan dan sebagai kohesi kolektivitas Tou Minahasa. Jika ritual di Watu Pinawetengan sebagai kolektivitas, maka menjadi faktor dominan untuk proses konstruksi sosial, yaitu para pelaku ritual saling mengeksternalisasi kedirian mereka untuk membangun sebuah kenyataan. ${ }^{62}$ Pada tataran ini sistem simbol menjadi lebih terbuka terhadap beragam konstruksi interpretasi makna dari subyektivitas para pelaku ritual yang saling berinteraksi.

Minahasa diklasifikasi dengan tiga kategori sistem agama dan simbol, yaitu mitos, foso, dan adat. Mitos merupakan cerita-cerita berdasarkan adat Minahasa; foso adalah praktek ritual orang Minahasa; sedangkan adat adalah sistem tingkah-laku sosial masyarakat Minahasa berdasarkan mitos dan foso Tou Minahasa (orang Minahasa). ${ }^{63}$ Ritual di Watu Pinawetengan berisi kategori-kategori sistem agama dan simbol Minahasa, sebab pada ritual terkandung unsur foso, narasi dari leluhur melalui orang yang sedang trans, dan adat melalui perilaku setiap anggota terhadap leluhur atau anggota lainnya. Secara lebih spesifik unsur simbol pada ritual bukan hanya ketiga kategori di atas. Sebab, setiap unsur pada ritual Minahasa bersifat simbolis, 
karena memiliki makna yang dapat dijelaskan dan sebagian sulit untuk diungkapkan dengan kata, tetapi bisa melalui rasa.

Simbol merepresentasikan kepercayaan Minahasa melalui makna. Simbol, dalam konstruksi yang paling sederhana, adalah benda, gambar, suara, tindakan, gerak tubuh, ucapan, dan hampir semua media lain yang berarti sesuatu atau yang memiliki makna. ${ }^{64}$ Geertz menjelaskan bahwa objek, tindakan, peristiwa, kualitas, atau hubungan apa pun yang berfungsi sebagai kendaraan untuk konsepsi adalah makna simbol. Lanjutnya, Geertz menjelaskan bahwa gagasan, abstraksi dari pengalaman yang ditetapkan dalam bentuk-bentuk yang dapat dipahami, perwujudan konkret gagasan, sikap, penilaian, kerinduan, atau kepercayaan merupakan simbol peristiwa sosial. ${ }^{65}$ Simbol adalah kendaraan untuk konsepsi dan penyimpanan ide-ide budaya, yang merupakan "makna" di balik kebudayaan. ${ }^{66}$ Masyarakat Minahasa mengonstruksi simbol agama dan budaya karena kepercayaan terhadap Yang Sakral.

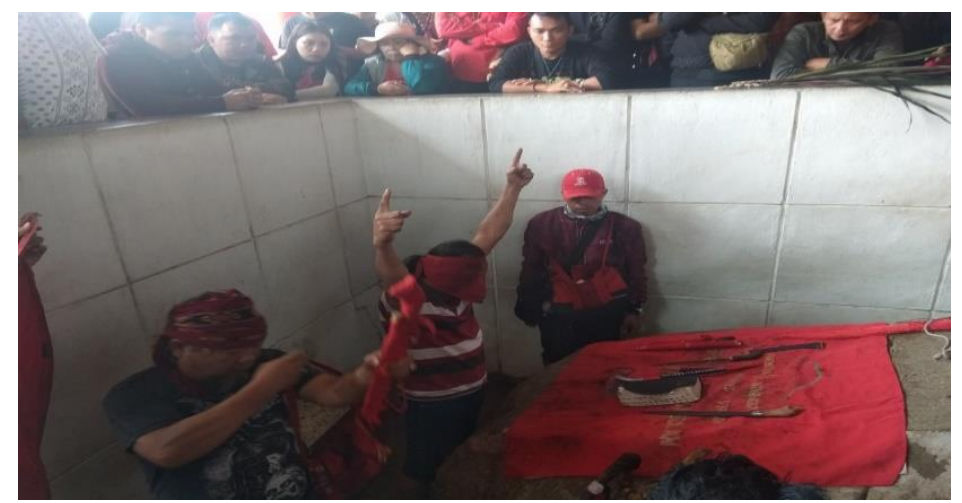

\section{Gambar 1. Alkitab yang digunakan dalam ritual di Watu Pinawetengan} (Sumber : Dokumentasi pribadi di Watu Pinawetengan Minahasai)

Saat ini praktik ritual Tou Minahasa di Watu Pinawetengan, biasanya digabungkan dengan simbol-simbol agama Kristen dan dimaknai dalam konteks sakral. Eller menjelaskan bahwa masyarakat dan agama memiliki ruang sakral. ${ }^{67}$ Simbol salib, Alkitab, doa, nyanyian, pengetahuan dan bahasa dari agama Kristen digunakan dalam proses ritual. Konstruksi simbol dalam ritual sebagai upaya memprodusir kediriannya sebagai Tou Minahasa-Kristen. ${ }^{68}$ Seorang Tonaas menjelaskan bahwa Alkitab merupakan kekuatan. ${ }^{69}$ Makna dibalik simbol kepercayaan Kristen turut diambil oleh pelaku ritual dan dihubungkan dengan simbol agama Malesung. Proses perubahan agama dan budaya paling mendasar melalui 
inovasi dan difusi. Di mana komunitas menemukan ide, objek, atau praktik baru, sehingga agama memiliki mitos, simbol, dan praktik ritual baru. ${ }^{70}$ Berger menyebut bahwa kebudayaan atau realitas akan terus dihasilkan oleh manusia. ${ }^{71}$ Meminjam perspektifnya Berger, dapat diartikan bahwa agama akan terus dihasilkan dan dihasilkan kembali oleh manusia. Karena itu, berbagai simbol pada ritual adalah representasi tou Minahasa sebagai homo symbolicus (makhluk simbol) dan homo religious (makhluk beragama). ${ }^{72}$ Pelaku ritual memperbaharui sistem simbol dan makna dalam ritual, namun tidak mengubah serta meninggalkan seluruh kategori agama Malesung (agama Minahasa) yang lama.

Sebenarnya tindakan menggunakan simbol Kristen dalam ritual adalah upaya dan aktivitas mengubah agama Kristen dan ritual Minahasa. Bagi Malinowski, proses di mana tatanan masyarakat yang ada, yaitu peradaban sosial, spiritual, dan materialnya ditransformasikan dari satu tipe ke tipe lainnya. ${ }^{73}$ Di mana agama Kristen (konteks Minahasa) ditransformasikan dari peribadatan dalam bangunan gereja dan dibangun atas dasar pietis (menolak kepercayaan Minahasa, terutama menyembah roh leluhur), menjadi para pelaku ritual dengan menggunakan simbol-simbol Kristen di Watu Pinawetengan. Hal yang sama juga terjadi pada agama Minahasa, di mana dalam proses sejarah Kekristenan menolak leluhur Minahasa dengan menggunakan ajaran Alkitab dan dogma gereja. Namun kini ritual di Watu Pinawetengan sebagai lokasi axis mundi disentuh dan dikonstruksi dalam diskursus Kekristenan. Oleh Berger menyebutnya sebagai proses mengonstruksi bahasa yang kemudian mengonstruksi simbol. $^{74}$ Bahasa-bahasa religius dan simbol-simbol sakral Kekristenan dikonstruksi dalam ritual Minahasa.

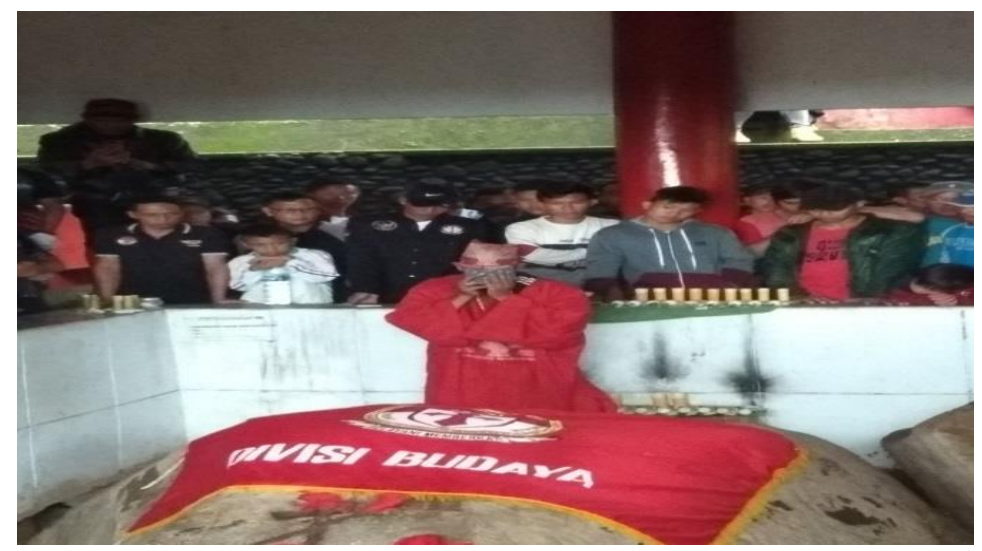

Gambar 2. Simbol Salib dalam ritual di Watu Pinawetengan 


\section{(Sumber : Dokumentasi pribadi di Watu Pinawetengan Minahasa)}

Ritual Tou Minahasa sangat berhubungan dengan roh para apo/dotu/opo/orang tua (leluhur Minahasa) yang merupakan entitas sakral dalam kepercayaan. Sebelum melakukan ritual, dilakukan persiapan dengan penuh kehatihatian karena dipercaya roh leluhur telah hadir. Misalnya pemotongan pinang dan digabungkan dengan kapur, saat lapisan pinang berwarna merah, dipercaya bahwa ada banyak leluhur yang hadir. ${ }^{75}$ Bagi anggota agama, simbol dapat berupa manifestasi, hasil, sisa-sisa kegiatan, peristiwa spiritual, atau alat yang melaluinya makhluk atau kekuatan bertindak. Simbol memberi manusia pengalaman langsung dari yang suci. Simbol juga memberi jejak realitas sakral dan dampaknya pada kehidupan manusia serta dunia. ${ }^{76}$ Karena itu, simbol sakral yang dikonstruksi oleh perilaku ritual akan berhadapan dengan diri mereka sendiri sebagai aktivitas membangun agama, oleh Berger membangun realitas. ${ }^{77}$ Realitas sakral turut dirasakan oleh komunitas penghayat Minahasa saat berurusan dengan simbol-simbol keagamaan.

Komunitas pelaku ritual masih dalam kepercayaan atau agama Minahasa, tetapi tetap beragama Kristen, inilah keunikan dari kepercayaan masyarakat Minahasa pada ritual di Watu Pinawetengan. Ketika agama Kristen telah dimasukkan ke dalam agama Minahasa, maka tidak bisa diserap kembali. ${ }^{78}$ Kekristenan menjadi faktisitas dalam Keminahasaan yang sui generis. Di dalam Minahasa dan Kristen tersebut terdapat beragam simbol sakral dengan makna kepercayaan. Simbol bisa memberi makna bagi masyarakat di saat simbol tersebut berisi nilai. Bagi orang beragama, simbol memiliki aspek sakral yang dipahami bermakna kudus. ${ }^{79}$ Henderson mengungkapkan bahwa simbol berada dalam kepercayaan masyarakat yang dapat ditemukan dalam ritual dan mitos masyarakat. ${ }^{80}$ Melalui entitas yang sakral, maka benda atau keadaan sekitar berubah menjadi berbeda dengan biasanya, karena yang sakral merupakan perwujudan dari hierofany. ${ }^{81}$

Saat memasuki tempat ritual, maka rokok dipasang sebagai bentuk relasi dengan leluhur. Pelaku ritual menyiapkan telur ayam rebus, pinang, nasi bungkus, rokok, cap tikus, tawaang, kemenyan, bambu, daun pisang, Alkitab dan lainnya yang dibutuhkan pada ritual. Hal ini bertujuan untuk menjamu leluhur sebagai tanda 
penghormatan atas kedatangan leluhur. Menurut seorang Tonaas, bahwa ritual harus dilakukan dengan persiapan, supaya tidak seperti permainan saja. Kalau tidak siap dengan berbagai bahan ritual, maka jangan melakukan ritual. Selanjutnya, Tonaas menjelaskan bahwa Alkitab merupakan kekuatan, penolong, dan meminta petunjuk kepada Amang Kasuruan (Tuhan) lewat leluhur. Sebab leluhur dari dahulu meminta kepada Yang di Atas, yaitu Amang Kasuruan (Tuhan) dan leluhur bersifat suci (tidak seperti manusia saat ini yang sudah kotor). ${ }^{82}$ Tuhan yang dimaksud oleh Tona'as berada dalam dua diskursus agama, yaitu Kristen dan Minahasa.

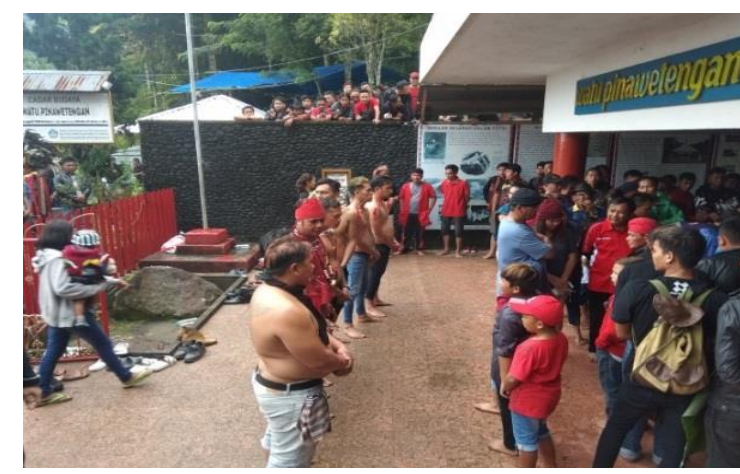

\section{Gambar 3. Proses ritual di Watu Pinawetengan}

Sumber : Dokumentasi pribadi di Watu Pinawetengan Minahasa

Leluhur memberikan nasihat dan juga menggunakan dasar ayat Alkitab. Setiap argumentasi yang diberikan oleh leluhur menjadi dasar penting dalam ritual, sebab dianggap sakral. Tanpa rasa penghormatan dari anggota terhadap isi ritual, maka ritual akan menjadi sia-sia. Pada saat leluhur membuka Alkitab untuk dibaca, maka setiap anggota mendengar dan menghormati tindakan dari leluhur. Alkitab menjadi penting dalam ritual. Lalu, simbol salib digunakan pada pakaian orang yang sedang trans. Setiap simbol yang digunakan memiliki hubungan dengan leluhur dan ingatan bersama. Dalam budaya dan agama tidak bisa dihindari adanya interaksi antar kebudayaan dan proses transaksi pengetahuan yang berbeda. ${ }^{83}$ Karena itu, fenomena perubahan ritual Minahasa yang menggunakan simbol Kristen, juga merupakan perubahan terhadap Kekristenan. Perubahan ini ditandai karena interaksi yang saling mengonstruksi satu dengan yang lain, yaitu penggunaan secara bersama simbol Minahasa dan Kristen dalam ritual. 


\section{Menjadi Minahasa Kristen}

Simbol pada praktik ritual orang Minahasa dipengaruhi oleh ingatan tentang identitas masyarakat yang beragama Kristen. Pertemuan antara kebudayaan (berisi agama) yang berbeda adalah realitas masyarakat di era kontemporer, oleh Sugiharto disebut sebagai era post-tradisi. Pertemuan dengan yang lain bukan lagi dipahami pada tataran hegemoni, tetapi bisa dilihat sebagai peluang untuk membuat canggih khazanah kebudayaan. ${ }^{84}$ Agama sebagai identitas penghayat kepercayaan Minahasa telah berorientasi pada dua karakteristik, yaitu agama Minahasa dan agama Kristen. Identitas ganda pada jati diri komunitas adalah salah satu faktor transisi agama. Bukan hanya esensi dari agama Minahasa yang telah berubah, tetapi esensi dari agama Kristen juga berubah. Kristen tidak lagi dipimpin oleh seorang pendeta atau pelayan khusus (konteks Kristen di Minahasa) dalam peribadatan, tetapi dipimpin oleh seorang Tonaas, Walian, atau Pakampetan. Sebaliknya, pelaku ritual tidak lagi hanya mendengar cerita-cerita lewat narasi tentang Minahasa, tetapi turut menggunakan teks agama Kristen (Alkitab). Alasan atas perubahan ini, karena: A) Terjadi pertemuan antara orang Minahasa dengan budaya/agama berbeda, yaitu Kristen pada zaman leluhur (masa Kolonial). B) Proses pemasukan ideologi dari agama luar (Kristen) atau Kristenisasi kepada masyarakat beragama lokal (Minahasa) melalui pendekatan kebudayaan (para zending belajar bahasa Minahasa untuk berkomunikasi). C) Terjadi resistensi dan kontestasi tentang identitas masing-masing agama. Zending menolak ritual Minahasa dan orang Minahasa menolak pihak zending. D) Penerimaan ideologi oleh pihak lokal (Minahasa). Melalui pendekatan dan waktu yang panjang oleh zending, maka perlahan orang Minahasa mulai menerima agama Kristen. E) Regenerasi pihak lokal (Minahasa) yang telah beragama Kristen. Keturunan Minahasa selanjutnya telah beragama Kristen. F) Revitalisasi agama (dalam budaya) Minahasa. Sebagian masyarakat Minahasa mengingat kembali identitas mereka sebagai Tou Minahasa, sehingga kembali melakukan ritual. G) Justifikasi kafir dan kontestasi. Masyarakat yang telah beragama Kristen menolak praktik ritual sebagai tindakan kafir. Sehingga, terjadi kontestasi antara masyarakat Minahasa yang beragama Kristen (tapi tidak melakukan praktik ritual) dengan yang 
melakukan ritual. H) Negosiasi ruang ideologis tentang pemaknaan simbol-simbol agama. Penghayat menggabungkan dua persepsi tentang Minahasa dan Kristen dengan mencari titik temu di antara keduanya. I) Ritual dan penambahan simbol Kristen. Proses ritual Minahasa melalui revitalisasi, tidak menghilangkan identitas agama Kristen, melainkan menggunakan simbol-simbol Kekristenan. Bahkan pelaku ritual tetap beribadah dalam peribadatan Kristen dan juga melakukan ritual. J) Legitimasi sakral/transenden/leluhur terhadap simbol baru dalam ritual. Seorang Tonaas, Walian (seperti seorang pendeta), atau Pakampetan (orang yang tubuhnya menjadi wadah bagi leluhur) (entah saat trans atau tidak) menggunakan Alkitab untuk dibaca, simbol salib tertera pada pakaian, doa dan kalimat (bahasa) agama Kristen digunakan pada proses ritual. K) Dominasi simbol. Perlu ditekankan, bahwa dominan pada ritual adalah simbol agama Minahasa (Malesung), dari pada Kristen. L) Perubahan makna dan sifat dinamis agama. Simbol-simbol Minahasa dan Kristen pada ritual memiliki makna yang saling terintegrasi dengan legitimasi yang sakral (leluhur). Para pelaku ritual lebih bersikap dinamis dalam beragama, yaitu dapat melakukan ritual dengan menerima perubahan simbol (berisi makna). Tanpa harus meninggalkan agama Kristen dan agama Minahasa, sebagai dua entitas yang tidak terpisahkan. Namun, tidak menutup diri untuk berinteraksi dengan agama di luar Kristen. ${ }^{85}$

Ritual agama Minahasa sebenarnya tidak menciptakan bentuk agama yang baru secara otentik, sebab masih banyak pendasaran dari kultus, simbol, dan mitos lama. Pelaku ritual masih berhubungan dengan roh leluhur, menggunakan bendabenda pusaka yang sakral, dan tetap berpegang pada cerita-cerita tentang ToarLumimu'ut. Walaupun di sisi lain, bahwa terdapat beragam interpretasi. Eller menjelaskan bahwa proses budaya Aborigin asli tidak menciptakan agama yang sepenuhnya baru tetapi permutasi dari bentuk-bentuk "tradisional" yang dapat dikenali. ${ }^{86}$ Malah yang lebih terlihat baru ada pada sisi agama Kristen, yaitu saat pelaku ritual dengan identitas Kristen tidak dipimpin oleh Pendeta atau Pelayan Gereja dalam ritual. Memang posisi antara pihak penjajah dan pihak terjajah bisa memiliki relasi. ${ }^{87}$ Sehingga antara Minahasa dan Kristen bisa terjadi adaptasi melalui kontak pengetahuan dan penerimaan dalam diri penghayat tentang kedua identitasnya (sebagai Minahasa dan Kristen). 
Selain dilihat dari segi adaptasi, perubahan agama juga diakibatkan karena pemenuhan kebutuhan. Menurut penjaga Watu Pinawetengan, ritual sering dilakukan untuk pengobatan sakit dan penyelesaian masalah. ${ }^{88}$ Seperti yang dijelaskan Eller bahwa, setiap gerakan adalah produk unik dari berbagai faktor sosial, kekuatankekuatan eksternal tertentu yang menghantamnya dan cara-cara tertentu di mana kekuatan-kekuatan itu terwujud. ${ }^{89}$ Pelaku ritual berusaha untuk menemukan keberadaan yang sakral melalui ritual, walaupun identitasnya adalah Kristen. Faktor kebutuhan manusia adalah pendorong terbesar dari perubahan suatu agama, karena manusia adalah makhluk yang bisa mendeterminasi pilihan-pilihan rasional menyangkut eksistensinya.

Perubahan agama Minahasa dan Kristen juga didasarkan atas revitalisasi agama Malesung (Minahasa) dengan basis kebudayaan melalui penerimaan. Menurut seorang Tona'as, Alkitab dimaknai berisi ajaran kebaikan sebagai pengingat pesan dari para leluhur. Ingatan dan pemaknaan ini mengakibatkan penguatan terhadap tradisi lama. ${ }^{90}$ Penguatan tradisi Minahasa ditandai dengan maraknya ritual di Watu Pinawetengan. Dalam konteks ritual tersebut, umumnya digunakan simbol dan ajaran Kristen. Ini pun membantah tesis dari Palm bahwa Minahasa hampir punah. Kenyataannya ritual Minahasa masih dilangsungkan, walau berpadanan dengan simbol Kristen. Dengan demikian, ritual dengan simbol Kristen turut membantu menghidupkan ritual Minahasa di masa kini. Seorang budayawan Minahasa juga menjelaskan bahwa Minahasa dan Kristen bisa dihubungkan dengan konsep kasih. ${ }^{91}$ Tona'as yang berbeda juga memiliki pemahaman bahwa dalam ajaran Kristen berisi kasih. ${ }^{92}$ Penerimaan terhadap ajaran agama Kristen didasarkan atas perbandingan, tentang apa yang bisa diterima dan tidak. Karena itu, melalui ajaran Kristen maka kepercayaan-kepercayaan Minahasa mulai dibangun kembali, dengan cara menginterpretasikan kembali tradisi atau ajaran agama tua Minahasa dalam diskursus Kekristenan.

Perubahan agama Minahasa dan Kristen adalah sebuah ambivalensi. Sebab Minahasa tidak lagi seperti Minahasa yang dulu dan Kristen tidak lagi seperti Kristen yang dulu. Beberapa konsep makna telah mengalami perubahan, saat simbol-simbol baru muncul. Perubahan ini yang menjadi keunikan dari masyarakat dengan budaya dan agama yang sudah mengalami proses transformasi. Minahasa masa kini tidak bisa 
menghindarkan diri dari proses perubahan zaman. Keterbukaan orang Minahasa tidak selamanya menjadi ancaman terhadap esensi identitas kepercayaan, sebab menciptakan ruang penerimaan yang lebih besar terhadap semua agama (dinamis).

Agama Minahasa yang siap terbuka dengan budaya atau agama lain telah mencapai tataran perubahan terhadap sikap primordial. Penguatan identitas kultural memang memiliki fungsi, tetapi keterbukaan lebih berfungsi pada era saat ini. Minahasa (pelaku ritual) hari ini bukan lagi seperti Minahasa zaman dahulu yang berperang dengan bangsa Barat. Kristen hari ini (konteks pelaku ritual) bukan lagi berperang (ideologi) dengan Minahasa soal ritual. Namun, Minahasa dan Kristen telah berdamai secara ideologi dan menemukan titik temu tentang bagaimana mengonsepkan tentang entitas Yang Sakral. Pemisahan antara Minahasa dan Kristen bukanlah jalan keluar, tetapi ancaman terhadap keterbukaan.

Perubahan agama adalah salah satu jalan supaya agama Minahasa bisa bertahan dan tetap ada di era kontemporer. Tanpa perubahan, mungkin agama Minahasa akan mengalami kehilangan eksistensi atau punah akibat perubahan zaman. Pada intinya, ritual di Watu Pinawetengan tetap mempertahankan berbagai dimensi sakral (perjumpaan dengan leluhur) supaya tidak kehilangan identitas. Simbol-simbol agama Kristen yang ada pada ritual adalah bagian dari mempertahankan eksistensi Keminahasaan dan eksistensi Kekristenan. Tindakan demikian direpresentasikan melalui ritual-ritual di Watu Pinawetengan oleh berbagai pelaku ritual dalam komunitasnya masing-masing.

\section{KESIMPULAN}

Perjumpaan antar budaya berdimensi keagamaan (sejak zaman leluhur) mengalami interaksi dan kontroversi, akibat pemaknaan terhadap simbol yang dipandang sakral oleh masyarakat Minahasa. Akibatnya kontestasi tidak bisa dihindarkan dan mewujud pada sikap mereduksi entitas kepercayaan dalam diri agama Minahasa oleh pihak Kristen. Namun, agama Minahasa tidak punah, tetapi mengubah wujud lewat simbol-simbol baru pada ritual di Watu Pinawetengan karena terjadi revitalisasi dan kebutuhan terhadap agama lokal. Perubahan simbol berarti perubahan pemaknaan. Saat makna berubah, maka agama yang lama turut berubah. Perubahan ini tidak lepas kendali atau merusak tatanan lama dalam ajaran Minahasa. 
Malahan, Minahasa semakin bisa bereksistensi dengan pemaknaan yang baru atau ditambahkannya nilai-nilai kepercayaan Kristen.

Bukan berarti Kristen yang mendominasi agama Minahasa dalam ritual, tetapi terdapat pemaknaan baru tentang Yang Sakral. Pada tataran ini, leluhur akhirnya memiliki tempat dalam konteks agama Kristen, sebab hampir semua penghayat dalam ritual beragama Kristen (identitas). Ini menjadi soal ambivalensi dan membawa arah baru bagi Minahasa dan Kristen di era kontemporer. Keterbukaan adalah hasil dari perjumpaan, tanpa meninggalkan seluruh jejak kultural religius Minahasa, melainkan ditambahkan konsep Kristen dengan penggunaan simbol serta maknanya. Konsep Opo Walian Wangko dari agama Minahasa, dipahami dalam konteks agama Kristen. Sebaliknya, konsep Tuhan dalam agama Kristen dipahami dalam konteks agama Minahasa. Dengan demikian, simbol-simbol sakral Minahasa dan Kristen yang berjumpa mewujud pada penyatuan makna.

Perjumpaan dengan interaksi makna pada waktu yang panjang dan dilakukan berulang-ulang menghasilkan perubahan terhadap ideologi, ritus, doa dan bahasa dari agama. Namun, perubahan agama membuat komunitas lebih bersifat dinamis dan defensif terhadap agama serta kebudayaan yang dianut. Legitimasi leluhur memberi peran signifikan terhadap konstruksi paradigma komunitas untuk tetap mempertahankan Keminahasaan dan Kekristenan, tanpa menganggap Minahasa sebagai milik dari Kristen saja. Fenomena komunitas penghayat kepercayaan Minahasa berjumpa pada titik kesatuan antara Minahasa (agama Malesung) dan Kristen lewat konstruksi pemaknaan simbol-simbol sakral dalam ritual.

\section{Endnotes:}

\footnotetext{
${ }^{1}$ Watu Pinawetengan adalah sebuah batu yang memiliki sejarah penting bagi orang Minahasa dalam hubungan dengan leluhur dan proses terbentuknya Minahasa. Batu ini memiliki banyak mitos tentang pembagian wilayah dan bahasa Minahasa. Karena itu, batu ini menjadi simbol penting tentang konsensus dari para leluhur Minahasa. Pada masa kini, batu ini menjadi tempat ritual bagi para pelaku ritual Minahasa sekaligus tempat wisata bagi para turis.

2 Denni H. R. Pinontoan, “Walian Dan Tuang Pandita”: Perjumpaan Agama Minahasa Dan Agama Kristen Pada Abad XIX (Yogyakarta: Pustaka Pranala, 2019), 48.

${ }^{3}$ Birgit Meyer, "Christianity and the Ewe Nation: German Pietist Missionaries, Ewe Converts and the Politics of Culture," Journal of Religion in Africa 32, no. 2 (2002): 167.

${ }^{4}$ Gratciadeo Tumbelaka, Izak Y M Lattu, and David Samiyono, "Negosiasi Identitas Kekristenan Dalam Ritual Kampetan Di Watu Pinawetengan Minahasa," Anthropos: Jurnal Antropologi Sosial Dan
} 
Budaya (Journal of Social and Cultural Anthropology) 6, no. 1 (n.d.): 1; Pinontoan and Pandita, Perjumpaan Agama Minahasa Dan Agama Kristen Pada Abad XIX; Paul R. Renwarin, Matuari Wo Tona'as Jilid 1 (Jakarta: Cahaya Pineleng, 2007); Michael Jacobsen, "On the Question of Contemporary Identity in Minahasa, North Sulawesi Province, Indonesia,” Asian Anthropology 1, no. 1 (2002): 31-58; David E. F. Henly, "Nationalism And Regionalism In A Colonial Context Minahasa In The Dutch East Indies”, Doctoral Dissertation (Australian National University, 1992).

5 Jack D. Eller, Introducing Anthropology of Religion (New York: Routledge, 2007), 160-61.

${ }^{6}$ Peter L. Berger, Langit Suci: Agama Sebagai Realitas Sosial, terj. Hartono (Jakarta: LP3ES, 1991), 7.

${ }^{7}$ Rulan Ahmadi, Metode Peneliatian Kualitatif (Yogyakarta: Ar-Ruzz Media, 2014), 14-15.

${ }^{8}$ Eller, Introducing Anthropology of Religion, 160.

${ }^{9}$ Mudji Sutrisno and Hendar Putranto, Teori-Teori Kebudayaan (Kanisius, 2005), 7.

${ }^{10}$ Eller, Introducing Anthropology of Religion, 161.

11 Allan Menzies, Sejarah Agama Agama: Studi Sejarah, Karakteristik Dan Praktik Agama-Agama Besar Di Dunia, terj. Dion Yulianto (Yogyakarta: Forum, 2014), 7.

${ }^{12}$ Daniel L. Pals, Seven Theories of Religion: Tujuh Teori Agama Paling Komprehensif, terj. Inyiak R. Muzir (Yogyakarta: IRCiSoD, 2012).

${ }^{13}$ Eller, Introducing Anthropology of Religion, 161.

${ }^{14}$ Sutrisno and Putranto, Teori-Teori Kebudayaan, 69.

${ }^{15}$ Eller, Introducing Anthropology of Religion, 162-63.

${ }^{16}$ Bambang Sugiharto, Kebudayaan Dan Kondisi Post-Tradisi: Kajian Filosofis Atas Permasalahan Budaya Abad Ke-21 (Yogyakarta: Kanisius, 2019), 65.

${ }^{17}$ Brian Morris, Antropologi Agama: Kritik Teori-Teori Agama Kontemporer (Yogyakarta: AK Group, 2003), 22.

${ }^{18}$ Eller, Introducing Anthropology of Religion, 182-84.

${ }^{19}$ Berger, Langit Suci: Agama Sebagai Realitas Sosial, 9.

${ }^{20}$ Sugiharto, Kebudayaan Dan Kondisi Post-Tradisi: Kajian Filosofis Atas Permasalahan Budaya Abad Ke-21, 50-51.

${ }^{21}$ Peter L Berger and Thomas Luckmann, "Tafsir Sosial Atas Kenyataan: Risalah Tentang Sosiologi Pengetahuan, Terj," Hasan Basari. Jakarta: LP3ES, 1990, xxiv.

22 Berger, Langit Suci: Agama Sebagai Realitas Sosial, 11.

${ }^{23}$ Berger, 5.

${ }^{24}$ Berger, 33.

${ }^{25}$ Berger, 35.

${ }^{26}$ Marhaeni L. Mawuntu, "Penetrasi Kekristenan Terhadap Agama Lokal Minahasa," dalam Agama Dan Budaya Nusantara Pasca Kristenisasi, ed. Izak Y.M. Lattu dan Tedi Kholiludin (Semarang: Lembaga Studi Sosial dan Agama Press, 2020), 193.

27 Toar dan Lumimuut adalah leluhur orang Minahasa. Melalui keturunan Toar dan Lumimuut, sehingga Minahasa bisa menjadi berkembang, sebab seluruh Tou Minahasa adalah anak mereka.

${ }^{28}$ Hasil wawancara dengan RT (Tona'as Minahasa), 10 Desember 2019, pukul 16.35 WITA, di Desa Warembungan, Minahasa.

${ }^{29}$ Denni H.R. Pinontoan, “Agama (Tua) Minahasa Dalam Mitos, Ritus, Dan Kultus,” in Agama Dan Kepercayaan Nusantara, ed. Sumanto Al Qurtuby and Tedi Kholiludin (Semarang: Lembaga Studi Sosial dan Agama Press, 2019), 74-76.

${ }^{30}$ Pinontoan, 83 .

${ }^{31}$ Pinontoan, 88 .

${ }^{32}$ Mawuntu, "Penetrasi Kekristenan Terhadap Agama Lokal Minahasa," 208.

${ }^{33}$ N. Graafland, Minahasa, Negeri, Rakyat, Dan Budayanya (Jakarta: Pustaka Utama Grafiti, 1991), 124.

${ }^{34}$ Gabriele Weichart, "Identitas Minahasa: Sebuah Praktik Kuliner,” Jurnal Antropologi Indonesia 74 (2004): 66.

${ }^{35}$ Pinontoan, “Walian Dan Tuang Pandita”: Perjumpaan Agama Minahasa Dan Agama Kristen Pada Abad XIX, ix.

${ }^{36}$ Graafland, Minahasa, Negeri, Rakyat, Dan Budayanya, 81.

${ }^{37}$ Pinontoan, "Walian Dan Tuang Pandita": Perjumpaan Agama Minahasa Dan Agama Kristen Pada Abad XIX, ix.

${ }^{38}$ Graafland, Minahasa, Negeri, Rakyat, Dan Budayanya, 82. 
${ }^{39}$ Renwarin, Matuari Wo Tona'as Jilid 1, 32.

${ }^{40}$ Pals, Seven Theories of Religion: Tujuh Teori Agama Paling Komprehensif, 239.

${ }^{41}$ Hasil wawancara dengan AW (penjaga situs budaya Watu Pinawetengan), 09 Desember 2019, pukul 16.30 WITA, di Watu Pinabetengan, Minahasa .

${ }^{42}$ Eller, Introducing Anthropology of Religion, 160.

${ }^{43}$ Sugiharto, Kebudayaan Dan Kondisi Post-Tradisi: Kajian Filosofis Atas Permasalahan Budaya Abad Ke-21, 14.

${ }^{44}$ Hasil wawancara dengan RT (Tona'as Minahasa), 10 Desember 2019, pukul 16.35 WITA, di Desa Warembungan, Minahasa.

${ }^{45}$ Pinontoan, “Walian Dan Tuang Pandita”: Perjumpaan Agama Minahasa Dan Agama Kristen Pada Abad XIX, 48.

${ }^{46}$ Edward W. Said, Orientalisme, terj. Asep Hikmat (Bandung: Pustaka, 2012), 15-16.

${ }^{47}$ Pinontoan, “Walian Dan Tuang Pandita”: Perjumpaan Agama Minahasa Dan Agama Kristen Pada Abad XIX, ix-x.

${ }^{48}$ Hasil wawancara dengan RT (Tona'as Minahasa), 10 Desember 2019, pukul 16.35 WITA, di Desa Warembungan, Minahasa.

${ }^{49}$ Pinontoan, “Walian Dan Tuang Pandita”: Perjumpaan Agama Minahasa Dan Agama Kristen Pada Abad XIX, 71.

${ }^{50}$ Berger, Langit Suci: Agama Sebagai Realitas Sosial, 13.

${ }^{51}$ Izak Y M Lattu, "Orality and Ritual in Collective Memory: A Theoretical Discussion," Jurnal Pemikiran Sosiologi 6, no. 2 (n.d.): 107.

${ }^{52}$ Mick Mordekhai Sopacoly, Izak Y M Lattu, and Ebenhaizer I Nuban Timo, "Sakralitas Waruga: Situs Suci Dan Identitas Kultural Masyarakat Minahasa," FIKRAH 7, no. 2 (2019): 232-33.

${ }^{53}$ Michel Foucault, Power/Knowledge: Wacana Kuasa/Pengetahuan, terj. Yudi Santosa (Yogyakarta: Benteng Budaya, 2002), 71.

${ }^{54}$ Eller, Introducing Anthropology of Religion, 161.

${ }^{55}$ Amartya Sen, Kekerasan Dan Identitas, terj. Arif (Tanggerang Selatan: Margin Kiri, 2016), 26.

${ }^{56}$ Mohammade Arkoun, et.all, Orientalisme vi a Vis Oksidentalisme (Jakarta: Pustaka Firdaus, 2008), 39-40.

${ }^{57}$ Pinontoan, “Walian Dan Tuang Pandita”: Perjumpaan Agama Minahasa Dan Agama Kristen Pada Abad XIX, 31-33.

${ }^{58}$ Hasil wawancara dengan RT (Tona'as Minahasa), 10 Desember 2019, pukul 16.35 WITA, di Desa Warembungan, Minahasa.

${ }^{59}$ Benyamin Supit and Matulandi Supit, Asal Usul Minahasa (Yogyakarta: Pustaka Pranala dan Lintang Rasi Aksara Books, 2019), 15.

${ }^{60}$ Bryan S. Turner, Relasi Agama Dan Teori Sosial Kontemporer, terj. Inyi (Yogyakarta: IRCiSoD, 2012), 93-94.

${ }^{61}$ Pals, Seven Theories of Religion: Tujuh Teori Agama Paling Komprehensif, 234-42.

${ }^{62}$ Berger, Langit Suci: Agama Sebagai Realitas Sosial, 35.

${ }^{63}$ David H. Tular, “Opoisme” Teologi Orang Minahasa (Tomohon: Letak Study Institute on Religion and Culture, 1993), 15.

${ }^{64}$ Eller, Introducing Anthropology of Religion, 55.

${ }^{65}$ Clifford Geertz, The Interpretation of Cultures (New York: Basic books, 1973), 91.

${ }^{66}$ Eller, Introducing Anthropology of Religion, 62.

${ }^{67}$ Eller, 66.

${ }^{68}$ Berger, Langit Suci: Agama Sebagai Realitas Sosial, 7.

${ }^{69}$ Hasil wawancara dengan AS (Tona'as Pakampetan Minahasa), 04 Januari 2020, puku 16.00 WITA, di Kota Bitung.

${ }^{70}$ Eller, Introducing Anthropology of Religion, 162.

${ }^{71}$ Berger, Langit Suci: Agama Sebagai Realitas Sosial, 8.

${ }^{72}$ David Cave, Mircea Eliade's Vision for A New Humanism (New York: Oxford University Press, 1993), 33-34.

${ }^{73}$ Eller, Introducing Anthropology of Religion, 161.

${ }^{74}$ Berger, Langit Suci: Agama Sebagai Realitas Sosial, 8.

${ }^{75}$ Hasil wawancara dengan S (Pelaku ritual), 12 Desember 2019, pukul 21.00 WITA, di Waruga Kali Pineleng. 
${ }^{76}$ Eller, Introducing Anthropology of Religion, 65.

${ }^{77}$ Berger, Langit Suci: Agama Sebagai Realitas Sosial, 9.

${ }^{78}$ Berger, 11.

79 Izak Y.M. Lattu, "Teologi Tanpa Tinta: Mencari Logos Melalui Etnografi Dan Folklore," in Membangun Gereja Sebagai Gerakan Yang Cerdas Dan Solider, ed. Fransiskus Purwanto and Agustinus Tri Edy Warsono (Yogyakarta: Sanata Dharma University Press, 2020), 91.

${ }^{80}$ Carl G. Jung, Manusia Dan Simbol-Simbol (Yogyakarta: Basabasi, 2018), 149-50.

${ }^{81}$ Mircea Eliade, Sacred and The Profane: The Nature of Religion (New York: A Harvest Book, 1956), 56.

${ }^{82}$ Hasil wawancara dengan AS (Tona'as Pakampetan Minahasa), 04 Januari 2020, pukul 16:10, di Kota Bitung.

${ }^{83}$ Sugiharto, Kebudayaan Dan Kondisi Post-Tradisi: Kajian Filosofis Atas Permasalahan Budaya Abad Ke-21, 15-16.

${ }^{84}$ Sugiharto, 14-15.

${ }^{85}$ Hasil wawancara dengan RT (Tona'as Minahasa), 10 Desember 2019, pukul 16:35, di Desa Warembungan, Minahasa dan hasil wawancara dengan AW (penjaga situs budaya Watu Pinawetengan), 19 Desember 2020, pukul 18.20 WITA, di Desa Pinabetengan.

${ }^{86}$ Eller, Introducing Anthropology of Religion, 65.

87 Budiawan, Ambivalensi Post-Kolonialisme Membedah Musik Sampai Agama Di Indonesia (Yogyakarta: Jalasutra, 2010), 73.

${ }^{88}$ Hasil wawancara dengan AW (penjaga situs budaya Watu Pinawetengan), 19 Desember 2020, pukul 18.20 WITA, di Desa Pinabetengan.

${ }^{89}$ Eller, Introducing Anthropology of Religion, 167.

${ }^{90}$ Hasil wawancara dengan RT (Tona'as Minahasa), 10 Desember 2019, pukul 16.35 WITA, di Desa Warembungan, Minahasa.

${ }^{91}$ Hasil wawancara dengan FW (Budayawan, akademisi dan pelaku ritual Minahasa), 28 Desember 2019, pukul 09:50, di Sonder, Minahasa.

${ }^{92}$ Hasil wawancara dengan AS (Tona'as Pakampetan Minahasa), 04 Januari 2020, pukul 16:10 WITA, di Kota Bitung.

\section{DAFTAR PUSTAKA}

Ahmadi, Rulan. Metode Peneliatian Kualitatif. Yogyakarta: Ar-Ruzz Media, 2014.

Arkoun, Mohammade. Orientalisme vi a Vis Oksidentalisme. Jakarta: Pustaka Firdaus, 2008.

Berger, Peter L. Langit Suci: Agama Sebagai Realitas Sosial. Terj. Hart. Jakarta: LP3ES, 1991.

Berger, Peter L, and Thomas Luckmann. "Tafsir Sosial Atas Kenyataan: Risalah Tentang Sosiologi Pengetahuan, Terj." Hasan Basari. Jakarta: LP3ES, 1990.

Budiawan. Ambivalensi Post-Kolonialisme Membedah Musik Sampai Agama Di Indonesia. Yogyakarta: Jalasutra, 2010.

Cave, David. Mircea Eliade's Vision for A New Humanism. New York: Oxford 
University Press, 1993.

David E. F. Henly. "Nationalism And Regionalism In A Colonial Context Minahasa In The Dutch East Indies.” Australian National University, 1992.

Edward W. Said. Orientalisme. Terj. Asep. Bandung: Pustaka, 2012.

Eliade, Mircea. Sacred and The Profane: The Nature of Religion. New York: A Harvest Book, 1956.

Eller, Jack D. Introducing Anthropology of Religion. New York: Routledge, 2007.

Geertz, Clifford. The Interpretation of Cultures. New York: Basic books, 1973.

Graafland, N. Minahasa, Negeri, Rakyat, Dan Budayanya. Jakarta: Pustaka Utama Grafiti, 1991.

Jacobsen, Michael. "On the Question of Contemporary Identity in Minahasa, North Sulawesi Province, Indonesia.” Asian Anthropology 1, no. 1 (2002): 31-58.

Jung, Carl G. Manusia Dan Simbol-Simbol. Yogyakarta: Basabasi, 2018.

Lattu, Izak Y.M. “Teologi Tanpa Tinta: Mencari Logos Melalui Etnografi Dan Folklore." In Membangun Gereja Sebagai Gerakan Yang Cerdas Dan Solider, edited by Fransiskus Purwanto and Agustinus Tri Edy Warsono. Yogyakarta: Sanata Dharma University Press, 2020.

Lattu, Izak Y M. "Orality and Ritual in Collective Memory: A Theoretical Discussion.” Jurnal Pemikiran Sosiologi 6, no. 2 (n.d.): 94-111.

Mawuntu, Marhaeni L. "Penetrasi Kekristenan Terhadap Agama Lokal Minahasa.” In Agama Dan Budaya Nusantara Pasca Kristenisasi, edited by Izak Y.M. Lattu and Tedi Kholiludin. Semarang: Lembaga Studi Sosial dan Agama Press, 2020.

Menzies, Allan. Sejarah Agama Agama: Studi Sejarah, Karakteristik Dan Praktik Agama-Agama Besar Di Dunia. Terj. Dion. Yogyakarta: Forum, 2014.

Meyer, Birgit. "Christianity and the Ewe Nation: German Pietist Missionaries, Ewe Converts and the Politics of Culture." Journal of Religion in Africa 32, no. 2 (2002): 167-99.

Michel Foucault. Power/Knowledge: Wacana Kuasa/Pengetahuan. Terj. Yudi. Yogyakarta: Benteng Budaya, 2002.

Morris, Brian. Antropologi Agama: Kritik Teori-Teori Agama Kontemporer. 
Yogyakarta: AK Group, 2003.

Pals, Daniel L. Seven Theories of Religion: Tujuh Teori Agama Paling Komprehensif.

Terj. Inyi. Yogyakarta: IRCiSoD, 2012.

Pinontoan, Denni H. R. “Walian Dan Tuang Pandita”: Perjumpaan Agama Minahasa

Dan Agama Kristen Pada Abad XIX. Yogyakarta: Pustaka Pranala, 2019.

Pinontoan, Denni H.R. “Agama (Tua) Minahasa Dalam Mitos, Ritus, Dan Kultus.” In Agama Dan Kepercayaan Nusantara, edited by Sumanto Al Qurtuby and Tedi Kholiludin. Semarang: Lembaga Studi Sosial dan Agama Press, 2019.

Renwarin, Paul R. Matuari Wo Tona'as Jilid 1. Jakarta: Cahaya Pineleng, 2007.

Sen, Amartya. Kekerasan Dan Identitas. Terj. Arif. Tanggerang Selatan: Margin Kiri, 2016.

Sopacoly, Mick Mordekhai, Izak Y M Lattu, and Ebenhaizer I Nuban Timo.

"Sakralitas Waruga: Situs Suci Dan Identitas Kultural Masyarakat Minahasa." FIKRAH 7, no. 2 (2019): 217-42.

Sugiharto, Bambang. Kebudayaan Dan Kondisi Post-Tradisi: Kajian Filosofis Atas Permasalahan Budaya Abad Ke-21. Yogyakarta: Kanisius, 2019.

Supit, Benyamin, and Matulandi Supit. Asal Usul Minahasa. Yogyakarta: Pustaka Pranala dan Lintang Rasi Aksara Books, 2019.

Sutrisno, Mudji, and Hendar Putranto. Teori-Teori Kebudayaan. Kanisius, 2005.

Tular, David H. "Opoisme” Teologi Orang Minahasa. Tomohon: Letak Study Institute on Religion and Culture, 1993.

Tumbelaka, Gratciadeo, Izak Y M Lattu, and David Samiyono. "Negosiasi Identitas Kekristenan Dalam Ritual Kampetan Di Watu Pinawetengan Minahasa.” Anthropos: Jurnal Antropologi Sosial Dan Budaya (Journal of Social and Cultural Anthropology) 6, no. 1 (n.d.): 1-9.

Turner, Bryan S. Relasi Agama Dan Teori Sosial Kontemporer. Terj. Inyi. Yogyakarta: IRCiSoD, 2012.

Weichart, Gabriele. "Identitas Minahasa: Sebuah Praktik Kuliner.” Jurnal Antropologi Indonesia 74 (2004). 